\title{
Increased serum ferritin levels in women with preeclampsia
}

\author{
Amal M. EIShahat*, Zakia M. Ibrahim*, Eman A. Kishk*, Rabab \\ A. Basuony*, Omima T. Taha* \\ DDepartment of Obstetrics and Gynecology, Faculty of Medicine, Suez \\ Canal University, Round Road, Ismailia 41111, EGYPT.
}

Correspondence

Amal M. EIShahat, MD.

Professor of Obstetrics and Gynecology, Department of Obstetrics and Gynecology

Faculty of Medicine, Suez Canal University.

Email:amalmsh2@yahoo.com

Zakia M. Ibrahim, MD

Professor of Obstetrics and Gynecology, Department of Obstetrics and Gynecology

Faculty of Medicine, Suez Canal University.

Email: zakiamahdyabolill@yahoo.com

\section{Eman A. Kishk, MD}

Professor of Obstetrics and Gynecology, Department of Obstetrics and Gynecology

Faculty of Medicine, Suez Canal University.

Email: tete5500@yahoo.com

\section{Rabab A. Basuony, MBBCH}

A resident of Obstetrics and Gynecology, Department of Obstetrics and Gynecology

Faculty of Medicine, Suez Canal University.

Email: rababameen33@gmail.com

\section{Omima T. Taha, MD (Corresponding author)}

Lecturer of Obstetrics and Gynecology, Department of Obstetrics and Gynecology

Faculty of Medicine, Suez Canal University.

Email: omimatharwat@yahoo.com

Tel: 01223423685

Running head: Serum ferritin in preeclampsia

Received Date: Feb 29, 2020

Accepted Date: Mar 02, 2020

Published Date: June 02, 2020

\section{ABSTRACT}

Aim: To study the correlation between serum ferritin level and the severity of preeclampsia.

Methods: This was a case-control study conducted in the emergency ward of Obstetrics and Gynecology Department of Suez Canal University Hospitals. We recruited sixty patients with preeclampsia and 60 normal pregnant women before parturition. All women were subjected to complete history and routine obstetric ultrasonography evaluation. Serum ferritin, serum iron, transferrin saturation, total iron-binding capacity, and unsaturated iron-binding capacity were assessed for all participants.

Results: The mean serum ferritin was significantly higher in mild and severe preeclampsia groups vs. the control group (33.27 \pm 6.9 and 69.47 $\pm 20.1 \mathrm{ng} / \mathrm{ml}$ versus $16.9 \pm 20.9 \mathrm{ng} \mathrm{ng} / \mathrm{ml}$, respectively, $\mathrm{p}$-value $<0.001$ ). Regarding, the mean serum iron level in the mild, severe preeclampsia and control groups, it was $201.87 \pm 58.13,219.4 \pm 53.1 \mu \mathrm{g} / \mathrm{dl}$ and $173.9 \pm$ $56.58 \mu \mathrm{g} / \mathrm{dl}$ respectively ( $\mathrm{p}$-value $<0.05$ ). There was a highly significant correlation between ferritin and each of systolic and diastolic blood pressures ( $r=0.8, \mathrm{p}<0.001$ and $\mathrm{r}=0.7, \mathrm{p}<0.001$ respectively). Conclusions: The level of serum ferritin was high in patients with preeclampsia, and it correlates well with the severity of the disease. Keywords: Ferritin, Iron stores, Preeclampsia.

\section{Introduction}

Preeclampsia is one of the worrisome concerns for pregnant women and physicians. Generally, 3\%-5\% of pregnancies are complicated with preeclampsia. It is a progressive disease with a variable mode of presentation and rate of progression ${ }^{1}$. Preeclampsia is a multisystemic disorder occurring after 20 weeks of gestation. In severe cases, it increases the risk of organ damage threatening the lives of both mother and baby ${ }^{2}$. Ferritin is a ubiquitous intracellular protein that stores iron and releases it in a controlled fashion. The protein is produced by almost all living organisms, including bacteria, algae, higher plants, and animals ${ }^{3}$. It is a major iron storage protein found not only in spleen, liver and bone marrow, but also in mucosal cells of the small intestine, in the placenta, kidney, testes, skeletal muscle, and in plasma. In pregnancy, serum ferritin concentration reaches the maximum level at 12 weeks gestation; it reaches a nadir in the third trimester ${ }^{4}$. Different researches were conducted to evaluate the serum level of ferritin in patients with preeclampsia, however; none of them was conducted in North Africa. The present research aimed to evaluate serum ferritin levels in women with preeclampsia and its correlation with disease severity.

\section{Patients and methods}

The study was carried out in the emergency Ward of Obstetrics and Gynecology Department of Suez Canal University Hospital from January 2016 to January 2018. The research ethics committee approved the study and informed written consent was obtained from all participants in the study.

The sample size was calculated based on serum ferritin concentration in patients with preeclampsia ${ }^{5}$. Assuming $\alpha=0.05$ and power $=0.80$, the total sample size was 60 pregnant. We decided to extend the study duration to include a more considerable number of patients. We recruited 120 patients, 60 pregnant women - study group- in the third trimester presented to the emergency ward for labor or termination of pregnancy and diagnosed as preeclampsia and were subdivided according to the severity of the disease into two groups: mild and severe preeclampsia $(\mathrm{n}=30$ for each group). Another 60 pregnant normotensive women with a normal pregnancy matched with the study group were enrolled as a control group.

The diagnosis of preeclampsia was based on the findings of elevation of blood pressure of $\geq 140 / 90 \mathrm{mmHg}$ (on two occasions at least 6 hours apart, with the last measure being considered in the analysis of the data) which is accompanied by proteinuria ( $\geq 0.3 \mathrm{~g}$ protein/24hours collected urine). Severe preeclampsia was defined according to the following criteria: elevated blood pressure $\geq 160 / 100 \mathrm{mmHg}$, proteinuria $\geq 5 \mathrm{~g}$ protein/24hours received urine or presence of headache, visual disturbances, epigastric pain, FGR, elevated liver enzymes or low platelets ${ }^{6}$.

Exclusion criteria were evidence of anemia (less than $10.5 \mathrm{mg} \%$ ) as this would influence serum ferritin levels as well as serum iron and total iron binding capacity ${ }^{7}$, systemic infection, history of chronic hypertension, renal disease, prior blood transfusion, iron supplementation during pregnancy, and urinary tract infection. Thorough medical and obstetric 
history and ultrasonographic evaluation were done to all women. Collection of a clean random urinary specimen to determine proteinuria using urinary dipstick followed by twenty-four hours urinary specimen was done. Ten $\mathrm{ml}$ of venous blood was withdrawn from all women for hemoglobin, hematocrit, Platelet count, alanine aminotransferase (ALT), aspartate aminotransferase (AST), bilirubin, creatinine, prothrombin time (PT), and partial thromboplastin time (PTT).

Serum ferritin measurement is not done routinely for patients admitted to the emergency ward. This was done for eligible patients for the study only. Serum ferritin (ng/dl) was assayed using a quantitative test system. This is a solid phase enzyme-linked immunosorbent assay (ELISA) kit purchased from Immunospec Corporation. Serum iron $(\mu \mathrm{g} / \mathrm{dl})$ and total iron-binding capacity (TIBC) (Mmol/l) were estimated by using the (colorimetric method) kit method. Unsaturated iron binding capacity (UIBC) (mg \%) denotes transferrin unbound to iron. It is about two-third of the iron-binding capacity, as normally about one third is saturated. The UIBC is calculated by the following formula: UIBC $(\mathrm{mg} \%)=\mathrm{TIBC}-$ Serum iron concentration.

\section{Statistical analysis:}

Data was statistically described in terms of mean and standard deviation, frequencies (number of cases) and percentages when appropriate. P values less than 0.05 were considered statistically significant. All statistical calculations were done using computer program SPSS (Statistical Package for the Social Science; SPSS Inc., Chicago, IL, USA) release 22 for Microsoft Windows. Chi-square test was used for categorical variables and $(\mathrm{t})$ test for continuous variables with normally distributed data. Non-normally distributed data was tested using non-parametric tests. Correlation coefficients were calculated between serum ferritin and systolic and diastolic blood pressures. Receiver operator characteristic curve was constructed for serum ferritin levels to have its cutoff point for the prediction of preeclampsia. Sensitivity and specificity were calculated.

Institutional review board: This study was conducted after approval by our research ethics committee in December 2015, with an approval number 1349 .

Informed consent: was obtained from all participants before recruitment.

\section{Results}

There were 137 women eligible for the study. Seventeen women were excluded because of anemia (6 patients in the control group, 7 patients in the mild preeclampsia group, and 4 patients in the severe preeclampsia group) leaving a total of 120 patients. Both groups were matched in their primary characters with the significant difference reported in the gestational age at termination of pregnancy, systolic, and diastolic blood pressure. There was no difference in the race and ethnicity of the recruited patients as well as other demographics (Table 1).

Table 1. Baseline characteristics among pre-eclampsia patients and controls:

\begin{tabular}{|c|c|c|c|c|}
\hline & $\begin{array}{l}\text { Mild } \\
\text { preeclampsia (30) } \\
\text { Mean } \pm \text { SD }\end{array}$ & $\begin{array}{l}\text { Severe } \\
\text { preeclampsia (30) } \\
\text { Mean } \pm \text { SD }\end{array}$ & $\begin{array}{l}\text { Control (60) } \\
\text { Mean } \pm \text { SD }\end{array}$ & p-value \\
\hline Age & $28.7 \pm 5.5$ & $28.7 \pm 5.9$ & $26.2 \pm 5.9$ & 0.3 (NS) \\
\hline $\begin{array}{l}\text { Gestational age (weeks) } \\
\text { Parity }\end{array}$ & $38.3 \pm 1.3$ & $34.9 \pm 3.3 \#$ & $39.3 \pm 0.9$ & $<0.001 *$ \\
\hline Primigravida & $4(26.67 \%)$ & $7(46.67 \%)$ & $7(23.3 \%)$ & \multirow[t]{2}{*}{0.3 (NS) } \\
\hline Multipara & $11(73.3 \%)$ & $8(53.3 \%)$ & $23(76.67 \%)$ & \\
\hline Systolic blood pressure & $144.67 \pm 4.8 \#$ & $177.5 \pm 13.2 \#$ & $115.6 \pm 48.6$ & $<0.001 *$ \\
\hline Diastolic blood pressure & $91.33 \pm 2.9 \#$ & $117.7 \pm 14.5 \#$ & $75.67 \pm 5.04$ & $<0.001 *$ \\
\hline
\end{tabular}

$\mathrm{NS}=$ not statistically significant

*Statistically significant difference between 3 groups (F-test)

\# Statistically significant difference versus control group

- Statically significant difference between mild and severe preeclampsia groups

Patients with preeclampsia were found to have significantly lower platelet, higher levels of ALT, AST, and serum creatinine than the control subjects (P-value $<0.001)$. There was no significant difference between both groups regarding hemoglobin levels, PT, and PTT (P-value $>0.05)($ Table 2). 


\section{Journal of Clinical Obstetrics and Gynecology Research}

Table 2. Laboratory characteristics among pre-eclampsia patients and controls:

\begin{tabular}{|c|c|c|c|c|}
\hline & $\begin{array}{l}\text { Mild } \\
\text { preeclampsia (30) } \\
\text { Mean } \pm \text { SD }\end{array}$ & $\begin{array}{l}\text { Severe } \\
\text { preeclampsia (30) } \\
\text { Mean } \pm \text { SD }\end{array}$ & $\begin{array}{l}\text { Control (60) } \\
\text { Mean } \pm \text { SD }\end{array}$ & p-value \\
\hline Platelets $(1000 / \mu \mathrm{L})$ & $215.27 \pm 49.1 \#$ & $184.1 \pm 64.4 \#$ & $280.2 \pm 57.6$ & $<0.001^{*}$ \\
\hline PTT (s) & $32.7 \pm 4.79$ & $32.9 \pm 6.1$ & $32.5 \pm 4.48$ & $0.9 \mathrm{NS}$ \\
\hline ALT(IU/L) & $18.33 \pm 8.6$ & $98.3 \pm 119.1 \#$ & $19.1 \pm 7.1$ & $<0.002 *$ \\
\hline $\operatorname{AST}(\mathbf{I U} / \mathbf{d l})$ & $23.0 \pm 5.3$ & $110.2 \pm 129.9 \#$ & $20.8 \pm 8.0$ & $<0.001^{*}$ \\
\hline Creatinine (mg/dl) & $0.8 \pm 0.1$ & $1.2 \pm 0.57$ & $0.68 \pm 0.25$ & $<0.001 *$ \\
\hline
\end{tabular}

$\mathrm{NS}=$ not statistically significant

*Statically significant difference between 3 groups (F-test)

\# Statically significant difference versus control group

- Statically significant difference between mild and severe preeclampsia groups

Patients with mild and severe preeclampsia have significantly higher levels of serum ferritin compared to control subjects $(33.27 \pm 6.9,69.47 \pm 20.1$ $\mathrm{ng} / \mathrm{ml}$ versus $16.9 \pm 20.9 \mathrm{ng} / \mathrm{ml}$, P-value $<0.001)$. The mean serum iron level in the mild, severe preeclampsia and control groups were significantly different $(201.87 \pm 58.13,219.4 \pm 53.1 \mu \mathrm{g} / \mathrm{dl}$ and $173.9 \pm 56.58 \mu \mathrm{g} / \mathrm{dl}$, respectively (p-value $<0.05)$. (Table 3 ).

Table 3. Comparison between the three study groups as regard serum ferritin, iron, TIBC, Transferrin saturation and UIBC.

\begin{tabular}{|l|l|l|l|l|l|}
\hline \multicolumn{2}{|l|}{} & $\begin{array}{l}\text { Mild } \\
\text { preeclampsia (30) } \\
\text { Mean } \pm \text { SD }\end{array}$ & $\begin{array}{l}\text { Severe } \\
\text { preeclampsia (30) } \\
\text { Mean } \pm \text { SD }\end{array}$ & $\begin{array}{l}\text { Control (60) } \\
\text { Mean } \pm \text { SD }\end{array}$ & p-value \\
\hline $\begin{array}{l}\text { Ferritin } \\
(\mathbf{n g} / \mathbf{m l})\end{array}$ & Non- adjusted & $33.27 \pm 6.9 \#$ & $69.47 \pm 20.1 \#$ & $16.9 \pm 20.9$ & $<\mathbf{0 . 0 0 1 *}$ \\
\cline { 2 - 6 } & Adjusted & $15.72 \pm 1.41$ & $124.6 \pm 13.66$ & $5.36 \pm 2.85$ & $<\mathbf{0 . 0 0 1 *}$ \\
\hline Iron $(\boldsymbol{\mu g} / \mathbf{d l})$ & $201.87 \pm 58.13$ & $219.4 \pm 53.1 \#$ & $173.9 \pm 56.58$ & $\mathbf{0 . 0 3 *}$ \\
\hline TIBC $(\boldsymbol{\mu m o l} / \mathbf{L})$ & $209.53 \pm 101.8 \#$ & $278.13 \pm 116.8 \#$ & $355.3 \pm 107.8$ & $<\mathbf{0 . 0 0 1 *}$ \\
\hline Transferrin saturation\% & $62.67 \pm 10.78$ & $68.67 \pm 16.45 \#$ & $58.17 \pm 13.75$ & $\mathbf{0 . 0 6}$ \\
\hline UIBC \% & $84.42 \pm 34.9 \#$ & $90.3 \pm 64.7 \#$ & $160 \pm 79.08$ & $<\mathbf{0 . 0 0 1 *}$ \\
\hline
\end{tabular}

*Statistically significant difference between 3 groups (F-test)

\# Statistically significant difference versus control

- Statistically significant difference between mild and severe preeclampsia groups 


\section{Journal of Clinical Obstetrics and Gynecology Research}

There was a highly significant correlation between ferritin and each of systolic and diastolic blood pressures $\mathrm{r}=0.8, \mathrm{p}<0.001$, and $\mathrm{r}=0.7, \mathrm{p}<0.001$, respectively (Figures 1 and 2 ).

Figure 1. Relation between ferritin and systolic blood pressure among the studied population

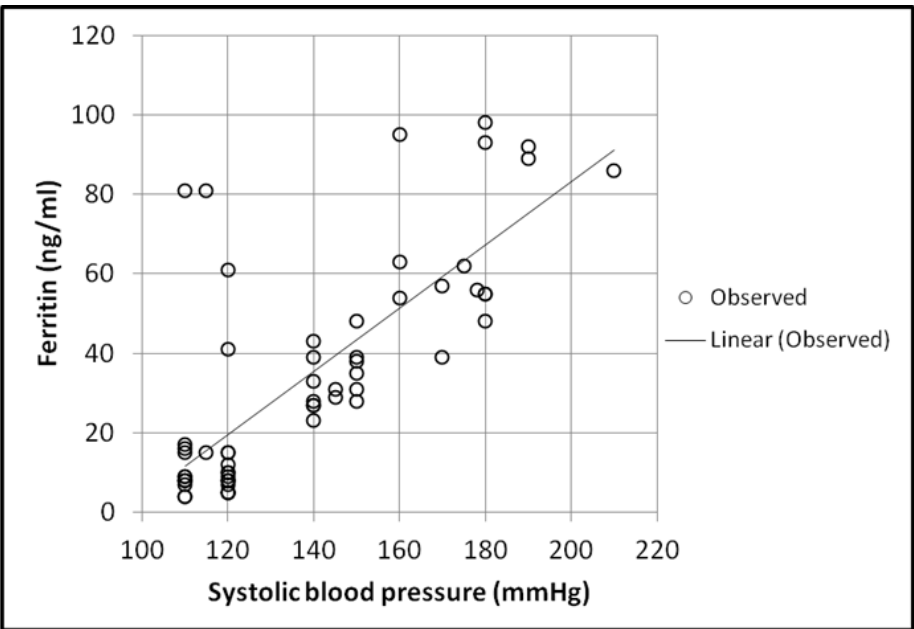

Figure 2. Relation between ferritin and diastolic blood pressure among the studied population.

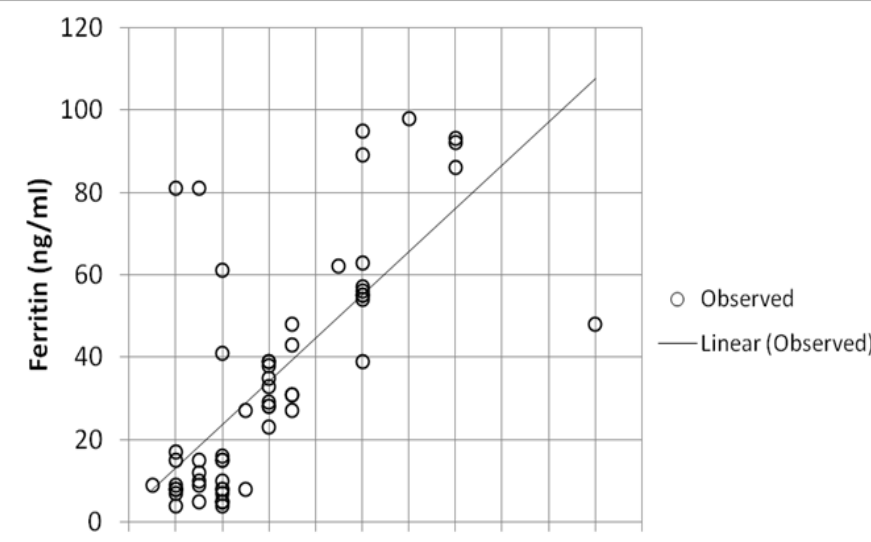

60708090100110120130140150160170

Diastolic blood pressure $(\mathrm{mmHg})$

Receiver operating characteristic curve (ROC) analysis has revealed that serum ferritin was a significant marker for the prediction of preeclampsia. The present study showed that the best cut off of serum ferritin (non- adjusted for gestational age) value for the prediction of preeclampsia was $>43 \mathrm{ng} / \mathrm{ml}$ with sensitivity and specificity of $93.3 \%$. An adjusted serum ferritin level of $16.01 \mathrm{ng} / \mathrm{ml}$ showed sensitivity of $85.0 \%$ and specificity of $91.7 \%$ for the prediction of preeclampsia. These levels are applied only for non- anemic preeclampsia cases (Figures $3 \mathrm{a}$ and $\mathrm{b}$ ).

Figure 3a: ROC Curve for Serum ferritin (non- adjusted for gestational age) as a predictor of preeclampsia.

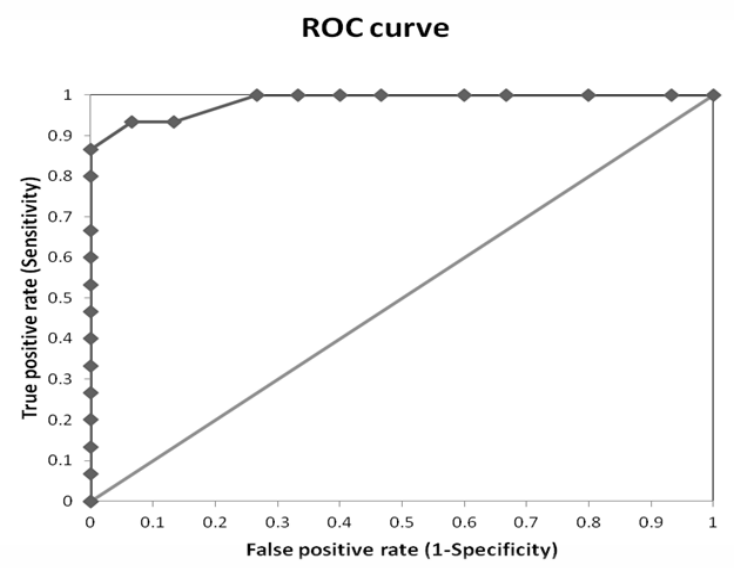

Figure 3b: ROC Curve for Serum ferritin (adjusted for gestational age) as a predictor of preeclampsia.

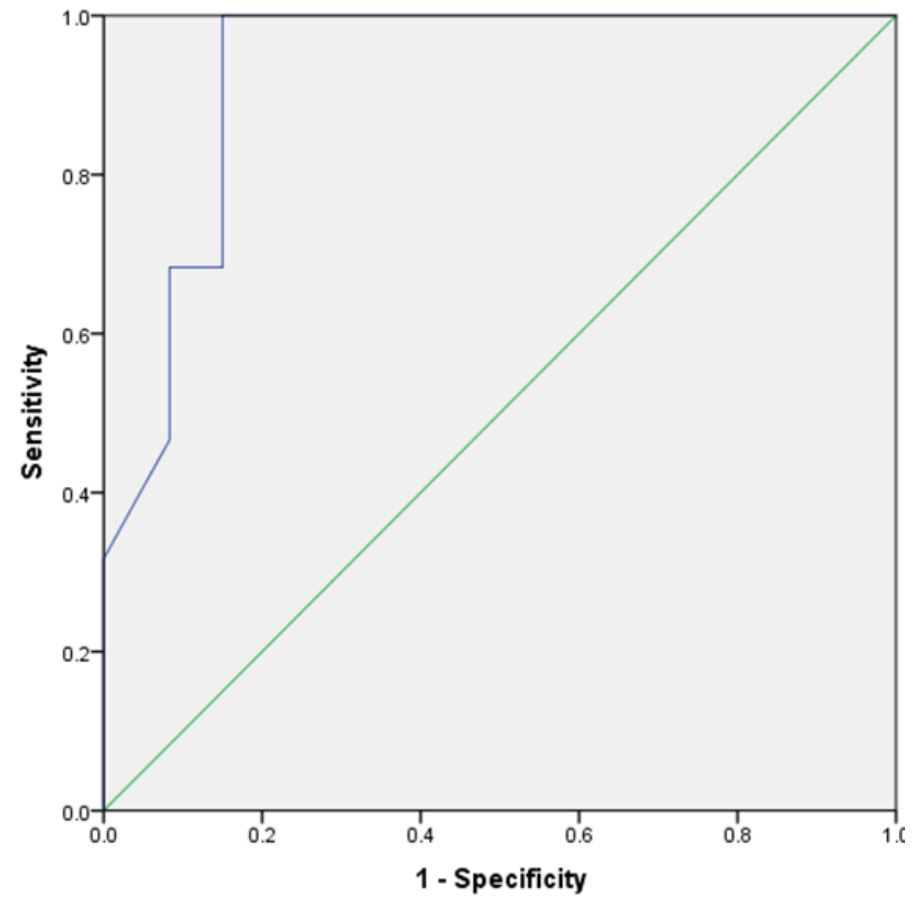




\section{Discussion}

The present study showed that patients with preeclampsia have higher levels of serum ferritin compared to control subjects $(33.27 \pm 6.9$ and $69.47 \pm 20.1 \mathrm{ng} / \mathrm{ml}$ versus $16.9 \pm 20.9 \mathrm{ng} / \mathrm{ml}, \mathrm{P}$-value $=0.001)$. These levels are applied only for non- anemic preeclampsia cases. Serum ferritin concentration ranges from $15-30 \mathrm{ng} / \mathrm{mL}$, where values below $15 \mathrm{ng} / \mathrm{mL}$ are specific for iron storage depletion. These results were consistent with previously reported ones $8,9,10$. Such increased levels would be explained by the reported abnormal iron and iron-binding protein in preeclampsia. Total serum ferritin concentrations were approximately fivefold higher in preeclampsia than in women with healthy pregnancies, which are contributed to increased cellular damage in preeclampsia. It was also hypothesized that ferritin synthesis is increased in preeclampsia. This is attributed to hepatocellular, rather than placental damage?

However, in another study, it was reported that increased serum iron and ferritin are rendered to decreased hepcidin levels, the peptide hormone that coordinates iron absorption and distribution, in women with preeclampsia ${ }^{10}$. Although, it was reported by Muhsin et al., 2016 that serum hepcidin levels were within the normal ranges in women with preeclampsia, yet significantly higher than controls ${ }^{11}$.

This striking increase in serum levels of iron and ferritin may even have the potential to be used diagnostically to warn of developing preeclampsia. Through effects on formation of oxygen free radicals and subsequent lipid peroxidation, ferritin might be a significant etiologic factor in the endothelial cell damage of preeclampsia ${ }^{8,9,12}$. According to Rahman et al., in their systematic review, mixed results for maternal anemia and preeclampsia exist. One study indicated that a hemoglobin concentration of $13.2 \mathrm{~g} / \mathrm{dL}$ during the first trimester was significantly associated with preeclampsia (OR: 1.73; 95\% CI: 1.07, 2.81). However, two other studies showed that low concentrations of hemoglobin during pregnancy were associated with preeclampsia (P-value 0.01$)^{13}$. This was the cause for excluding anemic patients from the study.

On the contrary, other studies reported no statistically significant relation between serum ferritin and preeclampsia ${ }^{14,15}$. Although they reported higher levels of ferritin in women with preeclampsia, it was not significant. This would be rendered to measuring serum levels of ferritin at 28-30 weeks, which was earlier than the current study.

Regarding serum iron level in the present study, it was significantly higher in preeclamptic patients than control subjects. Conflicting results exist

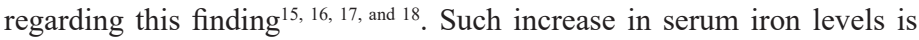
hazardous. It causes constant exposure of the intestinal mucosal cells to unabsorbed excess iron and oxidative stress ${ }^{6}$. Additionally, large doses of supplemental iron may build up the mother's iron stores and increase blood viscosity so that uteroplacental blood flow is impaired or that the excess iron intake could cause other toxic reactions ${ }^{19,20}$. It was also suggested that iron supplementation would lead to the development of preeclampsia through promoting hypoxia-inducible factor degradation, preventing normal placental development ${ }^{21}$.

Although TIBC is an unreliable indicator of the availability of iron to the tissues because of its fluctuations in the level due to infection or diurnal rhythm, it was significantly lower among preeclampsia patients compared to normotensive pregnant women. This was consistent with findings reported by previous studies ${ }^{18,22}$. The results allude to the possible contribution of released iron-free radicals from the ischemic placenta in preeclampsia to its etiology ${ }^{6}$. Also, increased transferrin saturation was noted to be doubled in patients with preeclampsia as a result of increased serum iron leading to lowered TIBC ${ }^{12}$.

Besides, we reported lower levels of unsaturated iron-binding capacity (UIBC) compared to the control group, which occurs as a consequence of oxidative stress leading to further oxidative stress by decreasing serum antioxidant buffering against redox-active iron $^{8}$. Receiver operating characteristic curve analysis has revealed that serum ferritin was a significant marker for the prediction of preeclampsia.

Research implications: To our knowledge, this is one of the first studies that try to clarify a cut off value of serum ferritin for the prediction of preeclampsia and its severity. Large-scale controlled studies to correlate between levels of ferritin and the prediction of preeclampsia are required. Further studies are required to evaluate the relation between iron supplementation and the level of serum ferritin among pregnant women at risk for the development of preeclampsia.

Strengths and limitations of the study: The current study included women with preeclampsia in comparison with normal pregnant women, which rendered our results more conclusive. A larger sample would be more informative. This is the first study to evaluate serum iron levels in women with preeclampsia in North Africa, as reported by Liu et al. in their meta-analysis ${ }^{24}$. Although we did not conduct a subgroup analysis that included early and late-onset preeclampsia, we evaluated mild and severe preeclampsia. Accordingly, serum ferritin concentration was significantly higher in patients with preeclampsia than in healthy pregnant women. Serum ferritin levels were not measured throughout the course of preeclampsia.

Disclosure statement:

$$
\text { - None. }
$$

References

1. Walle TA, Azagew AW. Hypertensive disorder of pregnancy prevalence and associated factors among pregnant women attending antenatal care at Gondar town health Institutions, North West Ethiopia 2017. Preg. Hypert. Volume 16, April 2019, Pages 79-84

2. Williams PJ, Gumaa KH, Scioscia M, et al. Inositol Phosphoglycan P-Type in Preeclampsia: A Novel Marker? Hypert. J. of the AHA; 2007; 49: 84.

3. Iancu TC. Ultrastructural aspects of iron storage, transport, and metabolism. J Neural Transm.; 2011; 118(3):329-35.

4. Akkurt MO, Akkurt O, Altay M, Coskun B, Erkaya S, Sezik M. Maternal serum ferritin as a clinical tool at 34-36 weeks' gestation for distinguishing subgroups of fetal growth restriction. JMFNM. Volume 30, 2017 - Issue 4

5. Toldi G, Stenczer B, Molvarec A, et al. Hepcidin concentrations and iron homeostasis in preeclampsia. Clin Chem Lab Med. Oct 2010; 48(10):1423-6.

6. Milman N, Agger A, Nielsen O. Iron status markers and serum erythropoietin in 120 mothers and newborn infants. AOGS.; 1994; 73: 200.

7. Adams P.C., Reboussin D.M., Press R.D., et al. Biological variability of transferrin saturation and unsaturated iron binding capacity The American Journal of Medicine; 2007, 120, 999.

8. Kwon I, Kwon JY, Lee JK. Maternal serum iron-related parameters in severe preeclampsia. Korean J Obstet Gynecol; 2007; 50:1064.

9. Hubel CA, Bodnar LM, Many A, Harger G, Ness RB, Roberts JM. Nonglycosylated ferritin predominates in the circulation of women with preeclampsia but not Intrauterine growth restriction. Am. Ass. for $\mathrm{Cl}$. Ch.; 2004; 50: 948.

10. Brunacci F, Rocha VS, De Carli E, Espósito BP, Ruano R, Colli C. Increased serum iron in preeclamptic women is likely due to low hepcidin levels. Nutr Res. 2018 May; 53:32-39. DOI: 10.1016/j. nutres.2018.03.005. Epub 2018 Mar 21.

11. Muhsin NA, Al-Mudalal SS, Hameed BM. Evaluation of the changes in iron homeostasis and hepcidin concentration in preeclamptic patients. Iraqi J. Hemat., 2016 vol.5, Issue 1.

12. Rayman MP, Barlis J, Evans RW, Redman CW, King LJ. Abnormal iron parameters in the pregnancy syndrome preeclampsia. AJOG; 2002; 187(2):412-8.

13. Rahman MDM, Abe SK, Rahman MDS et al., Maternal anemia and risk of adverse birth and health outcomes in low- and middle-income countries: systematic review and meta-analysis, The Am .J. of Cl. 


\section{Journal of Clinical Obstetrics and Gynecology Research}

Nut., Volume 103, Issue 2, February 2016, Pages 495-504, https://doi. org/10.3945/ajen.115.107896

14. Lao TT, Tam KF. Chan LY. Third-trimester iron status and pregnancy outcome in non-anemic women. Pregnancy unfavorably affected by maternal iron excess. Hum. Rep.; 2000; 151843-1848.

15. Biswas S, Roy A, Biswas S. Comparative study of copper, zinc, iron, ferritin, calcium, and magnesium levels in pregnancy-induced hypertension and normotensive primigravida mothers. Int J Res Med Sci.; 2016; 4(6):1879-1883

16. Sultana R, Ahmed S, Sultana N, Fazlul Karim SM. Iron Status in Pre-Eclampsia: A Case Comparison Study. Bangladesh J Med Biochem; 2012; 5(2): 53-55.

17. Siddiqui IA Jaleel A, Kadri HM, Saeed WA. Tamimi W. Iron status parameters in preeclamptic women. Ar. of Gyn. and Obst.; 2011; 284 (3): $587-591$.

18. Ugwaja EI, Ejikeme BN, Ugwu NC, Obeka NC. Comparison of plasma copper, iron, and zinc levels in hypertensive and non-hypertensive pregnant women in Abakaliki, South Eastern Nigeria. Pak J Nutr; 2010; 9: $1136-40$.

19. Taheripanah R, Bustani FP. Relation between Serum Ferritin and Iron Parameters with Preeclampsia. J. of Fam. and Rep. Heal.; 2007; 1(2): $87-91$.
20. Rush D. Nutrition and maternal mortality in the developing world. AmJ Clin Nutr; 2000; 72:212.

21. Scholl O. Iron status during pregnancy: setting the stage for mother and infant. Am J Clin Nutr; 2005; 81: 1218.

22. Smith TG, Robbins PA. Iron, preeclampsia and hypoxia-inducible factor. BJOG; 2007; 114: 1581.

23. Adam B, Malatyalioglu E, Alvur M, Talu C. Magnesium, zinc and iron levels in preeclampsia. JMFNM; 2001; 1(4): 246 - 250.

24. Liu JX, Chen D, Li MX, Hua Y. Increased serum iron levels in pregnant women with preeclampsia: a meta-analysis of observational studies. J. of Obst. and Gyn., 2018; DOI: 10.1080/01443615.2018.1450368.

Figure legend

Figure 1. Relation between ferritin and systolic blood pressure among the studied population

Figure 2. Relation between ferritin and diastolic blood pressure among the studied population.

Figure 3a: ROC Curve for Serum ferritin (non- adjusted for gestational age) as a predictor of preeclampsia.

Figure 3b: ROC Curve for Serum ferritin (adjusted for gestational age) as a predictor of preeclampsia. 